\title{
Pengaruh Periklanan, Promosi Penjualan dan Pemasaran Langsung Terhadap Keputusan Kunjungan Wisatawan
}

\author{
Heri Setiawan ${ }^{1 *}$ dan Jusmawi Bustan ${ }^{2}$ \\ ${ }^{1}$ Jurusan Administrasi Bisnis, Politeknik Negeri Sriwijaya, Indonesia \\ ${ }^{2}$ Jurusan Administrasi Bisnis, Politeknik Negeri Sriwijaya, Indonesia
}

\begin{abstract}
:
The development of tourism in Indonesia continues to grow rapidly and become one of the sectors that play a major role in developing the economy and improving people's welfare. This study aimed to determine the effect of advertising, sales promotion and direct marketing on decision tourist visits (study on Water Fun Palembang). Respondents selected is the visitor of Water Fun amounted to 120 people. The sampling technique used in this research is purposive sampling, the researchers used their own judgment by way of deliberate in selecting members of the population which are considered to provide specific information in accordance with the desired criteria researchers. The effect of advertising variable on the decision of tourist to visit is amounted to 0.391. The effect of sales promotion variables on the decision of tourist to visit is amounted to 0.240. There is an effect of direct marketing variables on the decision of the tourist to visit amounted to 0.334. Manager of Water Fun Palembang should maintain and where possible to improve the promotion through advertising, sales promotion and direct marketing so that tourists will still decide to visit Water Fun.
\end{abstract}

Keywords: advertising, sales promotion, direct marketing, tourist

\section{PENDAHULUAN}

Perkembangan pariwisata di Indonesia saat ini terus berkembang secara pesat dan menjadi salah satu sektor yang berperan besar dalam pengembangan perekonomian dan peningkatan kesejahteraan masyarakat. Hal tersebut didorong oleh perkembangan dunia pariwisata Indonesia yang terus mengalami peningkatan dari waktu ke waktu, terlihat dari bertambahnya jumlah wisatawan yang berkunjung ke daerah tujuan wisata di Indonesia, yang terkenal dengan keindahan alam, keramahan penduduk, dan keanekaragaman budayanya. Pada tingkat daerah, sektor ini diperkirakan akan menjadi penunjang pendapatan daerah yang kontribusinya di masa mendatang memiliki

*Email korespondensi:

Heri Setiawan

setyawanhery@yahoo.com prospek yang menguntungkan. Pariwisata diharapkan akan menjadi salah satu sektor utama yang mampu menjadi penyumbang devisa terbesar di Indoensia. Hal ini sejalan dengan pernyataan dari World Tourism Organization (WTO) yang menegaskan bahwa pariwisata akan menjadi salah satu industri terbesar pada abad 21 bersama-sama dengan telekomunikasi dan teknologi informasi. Sektor pariwisata menyumbang sebesar 9,07 miliar dolar AS bagi devisa Indonesia pada tahun 2012, berada pada urutan kelima pemberi kontribusi terbesar terhadap pendapatan Negara (Nirwandar, 2013). Hal tersebut yang kemudian menjadi tolak ukur bagi pemerintah untuk meningkatkan sektor pariwisata, dimulai dari sektor pariwisata daerah.

Kota Palembang merupakan salah satu kota di Propinsi Sumatera Selatan yang memiliki beragam obyek dan daya tarik wisata (ODTW), dengan moto kota yang 
berbunyi "Palembang Kota Bari". Salah satu prioritas pembangunan dan pendapatan Pemerintah Kota Palembang adalah sektor pariwisata. Sektor pariwisata merupakan salah satu sektor yang diharapkan mampu mendukung pendapatan asli daerah. Kota Palembang terletak pada posisi strategis jalur lintas Sumatera yang menjadi kota transit bagi masyarakat Pulau Sumatera. Kota Palembang merupakan pintu gerbang Provinsi Sumatera Selatan dengan keindahan Sungai Musi, peninggalan budaya dan sejarah berupa benteng, museum, Jembatan Ampera dan masih banyak lagi. Berbagai karya seni budaya dan peninggalan nenek moyang di Kota Palembang merupakan aset yang menarik untuk ditawarkan ke wisatawan. Oleh karena itu pengembangan sektor pariwisata di Kota Palembang harus dipandang sebagai potensi ekonomi yang sangat penting untuk menopang pembangunan di Sumatera Selatan.

Salah satu objek wisata air yang potensial dan banyak di kunjungi masyarakat di Kota Palembang adalah wahana air Water Fun yang terletak di kawasan Jaka Baring yang dapat ditempuh kurang lebih 15 menit dari pusat Kota Palembang dan akses ke lokasi wisata dapat ditempuh dari berbagai tempat. Kondisi kawasan wahana air Water Fun sangat potensial untuk dikembangkan, sesuai potensi dan kebutuhan masyarakat Kota palembang. PT. Sekawan Kontrindo sebagai pengelola objek wisata wahana air Water Fun menyadari bahwa pengambilan keputusan oleh konsumen tentunya berbedabeda, tergantung pada jenis keputusan pembelian produk pariwisata yang diinginkan. Pada dasarnya konsumen memiliki perilaku pembelian yang cukup rumit dengan adanya berbagai perbedaan yang terdapat pada produk dengan jenis yang sama, terlebih jika memilih produk pariwisata. Pada umumnya, konsumen yang ingin melakukan pembelian sebuah produk selalu mencari pengenalan produk yang tujuannya untuk melakukan perbandingan dan melakukan tinjauan langsung sesuai dengan bentuk promosi yang menjadi informasi bagi konsumen dalam mengambil sebuah keputusan (Kotler dan Keller, 2004). Disinilah yang menjadi salah satu alasan bagi wisatawan untuk lebih tertarik pada obyek wisata lain, yaitu karena mereka belum mendapat informasi yang lebih mendetail yang sekiranya dapat digunakan sebagai pembanding bahwa objek wisata wahana air Water Fun memiliki kelebihan dibanding objek wisata lainnya (persaingan). Atau kata lain persaingan dalam dunia bisnis pariwisata cukup mengandalkan promosi dalam meningkatkan jumlah kunjungannya.

Wahana air Water Fun sebagai salah satu wisata yang ada di Kota Palembang harus meningkatkan sistem pemasarannya terutama melalui kajian promosi yang kuat, melihat fakta bahwa promosi yang digunakan oleh PT. Sekawan Kontrindo masih terbilang minim. Jika mengacu pada selera pasar terhadap produk pariwisata, akan didapati bahwa akan terus terjadi perubahan yang begitu cepat, yang menuntut setiap usaha pariwisata, termasuk PT. Sekawan Kontrindo terus melakukan promosi yang lebih gencar lagi melalui pendekatan bauran promosi. Tujuan promosi adalah mendorong kesadaran konsumen atas merek produk, memberikan informasi atas produk, serta memberikan dorongan kepada konsumen pasca pembelian. Bauran promosi yang telah diterapkan oleh PT. Sekawan Kontrindo dalam mempromosikan objek wisata air Water Fun adalah periklanan, promosi Penjualan, pemasaran langsung. Promosi yang lebih gencar, maka akan meningkatkan keputusan pelanggan untuk berkunjung ke objek wisata air Water Fun dan manfaat pembangunan baik manfaat ekonomi, sosial, budaya, fisik, lingkungan kehidupan di lingkungan sekitar objek wisata akan tercapai, dan secara berkesinambungan akan tercapai pula target yang dituju oleh pemerintah.

\section{TINJAUAN PUSTAKA}

Tjiptono (2001) menyatakan bahwa promosi merupakan salah satu faktor penentu keberhasilan suatu program pemasaran. 
Betapapun berkualitasnya suatu produk, bila konsumen belum pernah mendengarnya dan tidak yakin bahwa produk itu akan berguna baginya, maka konsumen tidak akan pernah membelinya. Pada hakikatnya, promosi adalah suatu bentuk komunikasi pemasaran, yaitu aktivitas pemasaran yang berusaha menyebarkan informasi, mempengaruhi/ membujuk, dan/atau mengingatkan pasar sasaran atas perusahaan dan produknya agar bersedia menerima, membeli dan loyal pada produk yang ditawarkan perusahaan yang bersangkutan. Tujuan utama promosi menurut Kotler dan Keller (2004) adalah menginformasikan, mempengaruhi dan membujuk serta mengingatkan konsumen sasaran tentang perusahaan dan bauran pemasarannya. Menginformasikan dapat berupa mengenai keberadaan suatu produk baru, cara pemakaian, perubahan harga, jasajasa yang tersedia, dan membangun citra perusahaan. Dalam membujuk pelanggan sasaran, promosi bertujuan untuk membentuk pilihan merek, mengalihkan pilihan ke merek tertentu, mengubah persepsi konsumen terhadap atribut produk, mendorong pembelian dan mendorong pembeli menerima kunjungan wiraniaga. Sedangkan mengingat bertujuan untuk mengingatkan pembeli bahwa produk yang bersangkutan dibutuhkan dalam waktu dekat, mengingatkan pembeli akan tempat-tempat pemasaran produk, membuat pembeli tetap ingat walaupun tidak ada kampanye iklan dan menjaga agar ingatan pertama pembeli jatuh pada produk perusahaan.

\section{Periklanan (Advertising)}

Merupakan salah satu bentuk dari komunikasi impersonal yang digunakan oleh perusahaan baik barang / jasa. Tjiptono (2001) iklan merupakan salah satu bentuk bauran promosi yang paling banyak digunakan oleh suatu perusahaan dalam mempromosikan produknya. Paling tidak ini dapat dilihat dari besarnya anggaran belanja iklan yang dikeluarkan setiap perusahaan untuk merek-merek yang dihasilkan. Swastha (2002) menyatakan bahwa iklan adalah bentuk komunikasi tidak langsung, yang didasari pada informasi tentang keunggulan atau keuntungan suatu produk, yang disusun sedemikian rupa, sehingga menimbulkan rasa menyenangkan yang akan mengubah pikiran seseorang untuk melakukan pembelian. Berdasarkan uraian-uraian di atas, diketahui bahwa periklanan adalah seluruh proses yang meliputi penyiapan, perencanaan, pelaksanaan dan pengawasan iklan.

\section{Promosi Penjualan (Sales Promotion)}

Promosi Penjualan merupakan

bentuk persuasi langsung melalui penggunaan berbagai insentif yang dapat diatur untuk merangsang pembelian produk dengan segera dan / atau meningkatkan jumlah barang yang dibeli konsumen (Tjiptono, 2001). Promosi penjualan (sales promotion) merupakan bentuk persuasi langsung melalui penggunaan berbagai insentif yang dapat diatur untuk merangsang pembelian produk dengan segera dan / atau meningkatkan jumlah barang yang dibeli konsumen. Tjiptono (2001) menyatakan bahwa tujuan dari promosi penjualan sangat beraneka ragam. Melalui promosi penjualan, perusahaan dapat menarik konsumen baru, mempengaruhi konsumennya untuk mencoba produk baru, mendorong konsumen membeli lebih banyak, menyerang aktivitas promosi pesaing, meningkatkan impulse buying (pembelian tanpa rencana sebelumnya) atau mengupayakan kerjasama yang lebih erat dengan pengecer.

Sifat-sifat yang terkandung dalam promosi penjualan, diantaranya adalah komunikasi, insentif dan undangan (invitation). Menurut Kotler dan Keller (2004) menyatakan bahwa sifat komunikasi mengandung arti bahwa promosi penjualan mampu menarik perhatian dan memberi informasi yang memperkenalkan konsumen pada produk. Sifat insentif yaitu memberikan keistimewaan dan rangsangan yang bernilai bagi konsumen. Sedangkan sifat undangan adalah mengundang khalayak untuk membeli saat itu juga. Tjiptono (2001) menambahkan bahwa promosi penjualan yang dilakukan 
dapat dikelompokkan berdasarkan tujuan yang ingin dicapai. Pengelompokan tersebut adalah sebagai berikut:

1. Customer promotion yaitu promosi penjualan yang bertujuan untuk merangsang / mendorong konsumen untuk membeli.

2. Trade promotion yaitu promosi penjualan yang bertujuan untuk mendorong / merangsang pedagang grosir, pengecer, eksportir dan importir untuk memperdagangkan barang/jasa dari sponsor.

3. Sales-force promotion yaitu promosi penjualan yang bertujuan untuk memotivasi armada pemasaran.

4. Business promotion yaitu promosi penjualan yang bertujuan untuk memperoleh konsumen baru, mempertahankan kontak hubungan dengan konsumen, memperkenalkan produk baru, menjual lebih banyak kepada konsumen dan mendidik konsumen.

\section{Pemasaran Langsung (Direct Marketing)}

Menurut Tjipto (2000) pemasaran langsung atau sering disebut juga pemasaran langsung adalah suatu unsur yang paling efektif di dalam melakukan suatu bauran promosi. Pemasaran langsung merupakan bentuk tahapan-tahapan proses implementasi pemasaran yang dimulai dari penyediaan produk berupa barang/jasa, kemudian dilanjutkan dengan implementasi transaksi antara penjual dan pembeli, yang membentuk adanya perilaku berupa sikap dan tanggapan terhadap pemasaran yang diberikan berdasarkan tingkat preferensi, keyakinan dan tindakan pembelian. Ciri dari pemasaran langsung memiliki tiga ciri khusus yaitu:

1. Konfrontasi personal adalah pemasaran langsung mencakup hubungan yang luas, langsung dan interaktif antara dua pihak lain dengan lebih dekat.

2. Mempererat yaitu pemasaran langsung yang memungkinkan timbulnya berbagai hubungan mulai dengan hubungan pemasaran sampai hubungan persahabatan. Wiraniaga biasanya sudah benar-benar mengetahui minat pelanggan yang terbaik.

3. Tanggapan yaitu pemasaran langsung yang membuat pembeli merasa berkewajiban untuk mendengarkan pembicaraan wiraniaga.

Menurut Kotler dan Keller (2004) untuk mengembangkan komunikasi/promosi yang efektif maka diperlukan suatu program dengan sekitar delapan langkah, yaitu :

1. Mengidentifikasi Target Audience

Dalam tahap ini kita menentukan siapa target audience kita, target audience bisa merupakan individu, kelompok masyarakat khusus atau umum. Bila perusahaan telah melakukan segmentasi dan targeting, maka segmen itulah yang menjadi target audience.

2. Menentukan Tujuan Komunikasi

Setelah mengetahui target audience dan ciri-cirinya, maka kemudian dapat menentukan tanggapan apa yang dikehendaki. Perusahaan harus menentukan tujuan komunikasinya, apakah untuk menciptakan kesadaran, pengetahuan, kesukaan, pilihan, keyakinan, atau pembelian.

3. Merancang Pesan

Kemudian perusahaan harus menyusun pesan yang efektif. Idealnya suatu pesan harus mampu memberikan perhatian (attention), menarik (interest), membangkitkan keinginan (desire), dan menghasilkan tindakan (action).

4. Menyeleksi Saluran Komunikasi

Perusahaan harus menyeleksi saluransaluran komunikasi yang efisien untuk membawakan pesan. Saluran komunikasi itu bisa berupa komunikasi personal ataupun nonpersonal.

5. Menetapkan Jumlah Anggaran Promosi Menetapkan anggaran sangatlah penting karena untuk menentukan menggunakan media apa, juga tergantung pada anggaran yang tersedia.

6. Menentukan Bauran Promosi

Langkah berikutnya setelah menetapkan anggaran promosi adalah menentukan 


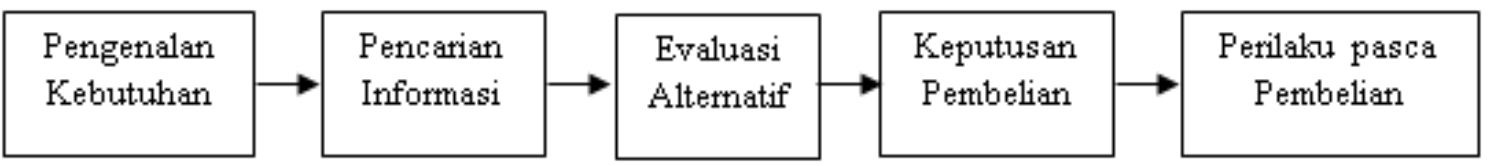

Gambar 1 Model Proses Keputusan Pembelian (Kotler dan Amstrong, 2001)

alat promosi apa yang akan digunakan, apakah melalui: advertising, personal selling, sales promotion atau public relation, dan lain-lain (atau bauran dari berbagai perangkat tersebut).

7. Mengukur Hasil-hasil Promosi

Setelah melaksanakan rencana promosi, perusahaan harus mengukur dampaknya pada target audience, apakah mereka mengenal atau mengingat pesan-pesan yang diberikan.

8. Mengelola dan Mengkoordinasi Proses Komunikasi

Karena jangkauan komunikasi yang luas dari alat dan pesan komunikasi yang tersedia untuk mencapai target audience, maka alat dan pesan komunikasi perlu dikoordinasikan.

\section{Keputusan Pembelian}

Keputusan pembelian merupakan hal yang lazim dipertimbangkan konsumen dalam proses pemenuhan kebutuhan akan barang maupun jasa. Pada kebanyakan orang, perilaku pembelian konsumen seringkali diawali dan dipengaruhi oleh banyaknya rangsangan (stimuli) dari luar dirinya, baik berupa rangsangan pemasaran maupun rangsangan dari lingkungan yang lain. Tahap-tahap dalam proses keputusan pembelian konsumen menurut Kotler dan Amstrong (2001) digambarkan dalam lima tahap sebagaimana dalam Gambar 1.

1. Pengenalan Kebutuhan

Merupakan tahap pertama di proses keputusan pembelian dimana konsumen mengenali masalah atau kebutuhan.

2. Pencarian informasi

Tahap ini konsumen digerakkan untuk mencari lebih banyak informasi, konsumen bisa lebih mudah melakukan pencarian informasi aktif.
3. Penilaian alternatif

Konsumen menggunakan informasi untuk mengevaluasi merek-merek alternatif dalam himpunan pikiran.

4. Keputusan pembelian

Tahap ini konsumen secara aktual membeli suatu suatu produk

5. Perilaku setelah pembelian

Setelah pembelian produk, konsumen akan mengalami suatu tingkat kepuasan atau ketidakpuasan tertentu.

Menurut Kotler dan Keller (2004), perilaku keputusan pembelian terbagi menjadi empat jenis, yaitu :

1. Perilaku pembelian kompleks

Konsumen melakukan perilaku pembelian kompleks ketika mereka sangatterlibat dalam pembelian dan merasa ada perbedaan yang signifikan antar merek. Konsumen mungkin sangat terlibat ketika produk itu mahal, beresiko, jarang dibeli, dan sangat memperlihatkan eskpresi diri.Umumnya konsumen harus mempelajari banyak hal tentang kategori produk.Pada tahap ini, pembeli akan melewati proses pembelajaran, mulamula mengembangkan keyakinan tentang produk, lalu sikap, dan kemudian membuat pilihan pembelian yang dipikirkan masak-masak.

2. Perilaku pembelian pengurangan disonansi (ketidaknyamanan)

Perilaku pembelian pengurangan disonansi terjadi ketika konsumen sangat terlibat dalam pembelian yang mahal, jarang dilakukan, atau beresiko, tetapi hanya melihat sedikit perbedaan antar merek. Setelah pembelian, konsumen mungkin mengalami ketidaknyamanan pasca pembelian ketika mereka mengetahui kerugian tertentu dari merek yang dibeli atau mendengar hal-hal 
menyenangkan tentang merek yang tidak dibeli.

3. Perilaku pembelian kebiasaan

Perilaku pembelian kebiasaan terjadi ketika dalam keadaan keterlibatan konsumen yang rendah dan sedikit perbedaan merek. Konsumen hanya mempunyai sedikit keterlibatan dalam kategori produk ini, mereka hanya pergi ke toko dan mengambil satu merek. Jika mereka terus mengambil merek yang sama, hal ini lebih merupakan kebiasaan daripada loyalitas yang kuat terhadap sebuah merek. Konsumen tidak secara ekstensif mencari informasi tentang merek, mengevaluasi karakteristik merek, dan mempertimbangkan keputusan tentang merek yang akan dibeli.

4. Perilaku pembelian mencari keragaman Perilaku pembelian mencari keragaman dalam situasi yang mempunyai karakter keterlibatan konsumen rendah, tetapi anggapan perbedaan merek yang signifikan. Dalam kasus ini, konsumen sering melakukan banyak pertukaran merek.

\section{METODE PENELITIAN}

Menurut Ferdinand (2006) populasi adalah gabungan dari seluruh elemen yang terbentuk peristiwa. Dalam penelitian ini, populasi penelitian adalah para pengunjung objek wisata air Water Fun. Sampel adalah subset dari populasi, terdiri dari beberapa anggota populasi. Sampel dalam penelitian ini berjumkah 120 orang. Responden yang dipilih adalah para pengunjung objek wisata air Water Fun. Teknik pengambilan sampel yang digunakan adalah purposive sampling, yaitu peneliti menggunakan pertimbangan sendiri dengan cara sengaja dalam memilih anggota populasi yang dianggap dapat memberikan informasi yang diperlukan atau unit sampel yang sesuai dengan kriteria tertentu yang diinginkan peneliti (Sugiyono, 2009). Kriteria yang digunakan adalah sampel yang merupakan para pengunjung objek wisata air Water Fun yang berusia $\geq 17$ tahun. Adapun pengambilan responden yang dijadikan sampel dilakukan di objek wisata air Water Fun Kota Palembang.

Instrumen dalam penelitian ini adalah kuisioner yang terdiri dari dua bagian yaitu: bagian pertama merupakan pertanyaan terbuka berisi pertanyaan mengenai identitas responden seperti usia dan jenis kelamin, sedangkan bagian kedua adalah pertanyaan tertutup meliputi semua variabel penelitian. Uji validitas dan reliabilitas dilakukan dengan menggunakan analisis regresi berganda yang dilakukan dengan menggunakan perangkat lunak SPSS versi 20.00 for Windows. Validitas yang digunakan dalam penelitian ini (content validity) menggambarkan kesesuaian sebuah pengukur data dengan apa yang akan diukur (Ferdinand, 2006). Biasanya digunakan dengan menghitung korelasi antara setiap skor butir instrumen dengan skor total (Sugiyono, 2009). Reliabilitas adalah alat untuk mengukur suatu kuesioner yeng merupakan indikator dari variabel atau konstruk. Suatu kuesioner dikatakan reliabel atau handal jika jawaban seseorang terhadap pertanyaan adalah konsisten atau stabil dari waktu ke waktu. Suatu konstruk atau variabel dikatakan reliabel jika memberikan nilai Cronbach Alpha > 0,60 (Nunnally, dalam Ghozali, 2006).

Metode analisis dalam penelitian ini menggunakan perhitungan regresi linier berganda. Adapun model persamaan analisis regresi penelitian ini adalah analisis regresi linier berganda dengan model persamaan sebagai berikut :

$$
\begin{aligned}
& Y_{1}=\alpha+\beta_{1} X_{1}+\beta_{2} X_{2}+\beta_{3} X_{3} \\
& \text { Keterangan : } \\
& \alpha=\text { koefisien konstanta } \\
& \beta=\text { koefisien regresi } \\
& X_{1}=\text { Periklanan } \\
& X_{2}=\text { Promosi Penjualan } \\
& X_{3}=\text { Pemasaran langsung } \\
& Y_{1}=\text { Keputusan Kunjungan }
\end{aligned}
$$

\section{HASIL DAN PEMBAHASAN}

Karakteristik responden berdasarkan umur, jenis kelamin, pekerjaan dan 
Tabel 1 Karakteristik Responden

\begin{tabular}{lcc}
\hline Karakteristik Responden & Jumlah $(\mathbf{n}=\mathbf{1 2 0})$ & \% \\
\hline Umur & 2 & 1.7 \\
< 20 tahun & 27 & 22.5 \\
21 - 30 tahun & 59 & 49.2 \\
31-40 tahun & 28 & 23.3 \\
41-50 tahun & & \\
Jenis Kelamin & 89 & 4.2 \\
Laki-Laki & 31 & 25.8 \\
Perempuan & & \\
Pekerjaan & 21 & 17.5 \\
PNS & 40 & 33.3 \\
Pegawai swasta & 42 & 35 \\
Wirausaha & 17 & 14.2 \\
Siswa/Mahasiswa & & \\
Pendidikan & 13 & 10.8 \\
SMA & 54 & 45 \\
D3 & 42 & 35 \\
S1 & 11 & 9.2 \\
S2 & & \\
\hline
\end{tabular}

Sumber: Data olahan, 2015

pendidikan dapat dijelaskan dalam Tabel 1. Berdasarkan jenis kelamin dari responden sebanyak 120 orang, terdiri dari laki-laki 89 orang atau sebesar $74,2 \%$ dan perempuan sebesar $25,8 \%$ atau 31 orang. Umur wisatawan Objek Wisata Air Water Fun Kota Palembang dapat dijelaskan sebagai berikut: responden berumur $<20$ tahun sebesar $1,7 \%$ atau 2 orang, umur 21-30 tahun sebesar $22,5 \%$ atau 27 orang, umur 31-40 tahun sebesar 49,2\% atau 59 orang, umur 41-50 tahun sebesar $23,3 \%$ atau 28 orang. Umur responden $>50$ tahun sebesar 3,3\% atau 4 orang. Wisatawan Objek Wisata Air Water Fun Kota Palembang berdasarkan jenis pekerjaan menunjukkan bahwa $17,5 \%$ atau 21 orang sebagai PNS, 33,3\% atau 40 orang pegawai swasta, $35 \%$ atau 42 orang wiraswasta, dan $14,2 \%$ atau 17 orang sebagai siswa/mahasiswa. Pendidikan wisatawan Objek Wisata Air Water Fun Kota Palembang yang menjadi responden yaitu: pendidikan SMA sebesar $10,8 \%$ atau 13 orang, berpendidikan Diploma sebesar $45 \%$ atau 54 orang, berpendidikan Sarjana sebesar $35 \%$ atau 42 orang dan berpendidikan pascasarjana sebesar $9,2 \%$ atau 11 orang.
Uji validitas dilakukan dengan mengunakan korelasi product moment, dimana $r$ tabel adalah 0,1509. Berdasarkan pengujian yang telah dilakukan untuk variabel bebas dan variabel tergantung pada setiap item menunjukkan $r$ hitung $>0,1509$, hal ini menunjukkan bahwa seluruh data yang di uji adalah valid. Berdasarkan analisis data diperoleh hasil perhitungan $r$ hitung variabel periklanan, promosi penjualan, pemasaran langsung, dan keputusan kunjungan wisatawan memiliki nilai $r$ hitung lebih besar dari $r$ tabel, ini berarti bahwa data variabel periklanan, promosi penjualan, pemasaran langsung, dan keputusan kunjungan wisatawan secara umum valid dan handal, sehingga kuisioner yang digunakan dapat diikutkan pada analisis selanjutnya.

Uji reliabilitas dilakukan untuk mengetahui sejauh mana tingkat kehandalan data yang diperoleh untuk diteliti. Suatu variabel dikatakan reliabel (handal) jika jawaban responden terhadap pertanyaan konsisten atau stabil dari waktu ke waktu. Suatu variabel dikatakan reliabel jika nilai $r$ hitung lebih besar dari Cronbach Alpa 0,60 (Nunaly, 1967). 
Uji F (Uji Simultan)

Berdasarkan rumusan masalah penelitian, maka variabel penelitian dikelompokkan menjadi variabel bebas (independent variable) dan variabel terikat (dependent variable). Variabel bebas dalam penelitian ini adalah periklanan, promosi penjualan, pemasaran langsung sedangkan variabel terikat adalah keputusan kunjungan wisatawan. Untuk mengetahui pengaruh periklanan, promosi penjualan, dan pemasaran langsung terhadap keputusan kunjungan wisatawan maka akan di lihat dari

Tabel 2 Pengaruh Periklanan, Promosi Penjualan, dan Pemasaran Langsung Terhadap Keputusan Kunjungan Wisatawan

\begin{tabular}{|l|r|r|r|r|}
\hline Model & $\mathrm{R}$ & $\mathrm{R}$ Square & $\begin{array}{c}\text { Adjusted } \\
\mathrm{R} \text { Square }\end{array}$ & $\begin{array}{c}\text { Std. Error of } \\
\text { the Estimate }\end{array}$ \\
\hline 1 & $.816^{\mathrm{a}}$ & .666 & .658 & 1.7887800 \\
\hline
\end{tabular}

a. Predictors: (Constant), Pemasaran Langsung (X3), Promosi Penjualan (X2), Periklanan (X1)

Sumber: Data olahan, 2015

Tabel 3 Hasil Uji Hipotesis

\begin{tabular}{|c|c|c|c|c|c|c|}
\hline Model & & $\begin{array}{l}\text { Sum of } \\
\text { Squares }\end{array}$ & df & Mean Square & $\mathrm{F}$ & Sig. \\
\hline \multirow[t]{3}{*}{1} & Regression & 741.331 & 3 & 247.110 & 77.228 & $.000^{\mathrm{a}}$ \\
\hline & Residual & 371.169 & 116 & 3.200 & & \\
\hline & Total & 1112.500 & 119 & & & \\
\hline
\end{tabular}

a. Predictors: (Constant), Pemasaran Langsung (X3), Promosi Penjualan (X2), Periklanan (X1)

b. Dependent Variable: Keputusan Berkunjung $(\mathrm{Y})$

Sumber: Data olahan, 2015

hasil perhitungan SPSS dalam model summary, khususnya angka $\mathrm{R}$ square. Berdasarkan analisis data untuk independen variabel periklanan, promosi penjualan, dan pemasaran langsung dan dependen variabel keputusan kunjungan wisatawan, diperoleh hasil analisisnya sebagaimana dijelaskan pada Tabel 2.

Besarnya angka R square (r2) adalah 0,666. angka tersebut dapat digunakan untuk melihat besarnya pengaruh periklanan, promosi penjualan, dan pemasaran langsung terhadap keputusan kunjungan wisatawan dengan cara menghitung Koefisien Determinasi (KD). Adapun cara menghitung Koefisien Determinasi (KD) dengan menggunakan rumus sebagai berikut:

$$
\begin{aligned}
& \mathrm{KD}=\mathrm{r} 2 \times 100 \% \\
& \mathrm{KD}=0,666 \times 100 \%
\end{aligned}
$$

$\mathrm{KD}=66,6 \%$

Angka tersebut mempunyai maksud bahwa pengaruh variabel periklanan, promosi penjualan, dan pemasaran langsung terhadap keputusan kunjungan wisatawan sebesar $66,6 \%$, sedangkan sisanya sebesar $33,4 \%(100 \%-66,6 \%)$ dipengaruhi oleh faktor lain. Variabel keputusan kunjungan wisatawan dapat diterangkan dengan menggunakan variabel periklanan, promosi penjualan, dan pemasaran langsung sebesar $66,6 \%$, sedangkan pengaruh sebesar 33,4 \% disebabkan oleh variabel lain di luar model. Kemudian, untuk mengetahui apakah model regresi di atas sudah benar atau salah, diperlukan uji hipotesis. Uji hipotesis menggunakan angka $\mathrm{F}$ sebagaimana tertera dalam Tabel 3. 
Tabel 4 Pengaruh Periklanan, Promosi Penjualan, dan Pemasaran Langsung Terhadap Keputusan Kunjungan Wisatawan Secara Parsial

\begin{tabular}{|c|c|c|c|c|c|c|}
\hline \multirow[b]{2}{*}{ Mod } & & \multicolumn{2}{|c|}{$\begin{array}{c}\text { Unstandardized } \\
\text { Coefficients }\end{array}$} & \multirow{2}{*}{$\begin{array}{c}\text { Standardized } \\
\text { Coefficients } \\
\text { Beta }\end{array}$} & \multirow[b]{2}{*}{$\mathrm{t}$} & \multirow[b]{2}{*}{ Sig. } \\
\hline & & B & Std. Error & & & \\
\hline \multirow[t]{4}{*}{$\overline{1}$} & (Constant) & -3.190 & 1.584 & & -2.014 & .046 \\
\hline & Periklanan (X1) & .283 & .053 & 391 & 5.388 & .000 \\
\hline & Promosi Penjualan (X2) & .309 & .090 & .240 & 3.424 & .001 \\
\hline & $\begin{array}{l}\text { Pemasaran Langsung } \\
\text { (X3) }\end{array}$ & .400 & .081 & .334 & 4.955 & .000 \\
\hline
\end{tabular}

a. Dependent Variable: Keputusan Berkunjung $(\mathrm{Y})$

Sumber: Data olahan, 2015

Pengujian dapat dilakukan dengan dua cara. Pertama, dengan membandingkan besarnya angka Fhitung dengan Ftabel. Cara kedua ialah dengan membandingkan angka taraf signifikansi (sig) hasil penghitungan dengan taraf signifikansi $0,05 \quad(5 \%)$. Menggunakan cara pertama atau membandingkan besarnya angka Fhitung dengan Ftabel. Fhitung dari pengolahan SPSS diperoleh nilai sebesar 77.228. Selanjutnya menghitung $F$ tabel dengan ketentuan sebagai berikut: taraf signifikansi 0,05 dan Derajat Kebebasan (DK) dengan ketentuan numerator: jumlah variabel -1 atau 4-1 = 3; dan denumerator: jumlah kasus -2 atau $120-2=118$. berdasarkan ketentuan tersebut diperoleh angka Ftabel sebesar 3,2288. Berdasarkan hasil perhitungan diperoleh angka Fhitung sebesar 77.228 > Ftabel sebesar 3,2288 sehingga Ho ditolak dan $\mathrm{H} 1$ diterima. Artinya ada pengaruh antara variabel periklanan, promosi penjualan, dan pemasaran langsung terhadap keputusan kunjungan wisatawan. Dengan demikian, model regresi diatas sudah layak dan benar. Menggunakan cara kedua atau membandingkan besarnya angka taraf signifikansi (sig) penelitian dengan taraf signifikansi sebesar 0,005. Berdasarkan perhitungan angka signifikansi sebesar 0,000 $<0,05$, Ho ditolak dan $\mathrm{H} 1$ diterima. Artinya ada pengaruh antara variabel periklanan, promosi penjualan, dan pemasaran langsung terhadap keputusan kunjungan wisatawan.

\section{Uji t (Uji Parsial)}

Analisis untuk melihat besarnya pengaruh variabel periklanan, promosi penjualan, dan pemasaran langsung terhadap keputusan kunjungan wisatawan secara parsial, digunakan uji t, sedangkan untuk melihat besarnya pengaruh digunakan angka Beta atau Standardized Coefficient pada Tabel 4.

Untuk melihat apakah ada pengaruh variabel periklanan terhadap keputusan kunjungan wisatawan dilakukan langkah analisis sebagai berikut:

Pertama: Menentukan hipotesis

Ho: Tidak ada pengaruh antara variabel periklanan terhadap keputusan kunjungan wisatawan.

H1: Ada pengaruh antara variabel periklanan terhadap keputusan kunjungan wisatawan.

Kedua: Menghitung besarnya angka $\mathrm{t}$ hitung

Hasil penghitungan SPSS diperoleh angka $t$ hitung sebesar 5,388.

Ketiga: Menghitung besarnya angka $t_{\text {tabel }}$ dengan ketentuan sebagai berikut: Taraf signifikansi 0,05 dan Derajat Kebebasan (DK) dengan ketentuan $\mathrm{DK}=\mathrm{n}-2$, atau $120-2=118$. Berdasarkan ketentuan tersebut diperoleh angka $\mathrm{t}$ tabel sebesar 1.6579 .

Berdasarkan hasil penghitungan diperoleh angka $\mathrm{t}$ hitung sebesar 5,388 $>\mathrm{t}$ tabel sebesar 1.6579 maka Ho ditolak dan H1 diterima. Artinya ada pengaruh antara 
variabel periklanan terhadap keputusan kunjungan wisatawan. Besarnya pengaruh variabel periklanan terhadap keputusan kunjungan wisatawan sebesar 0,391 atau $39,1 \%$.

Untuk melihat apakah ada pengaruh antara variabel promosi penjualan terhadap keputusan kunjungan wisatawan dilakukan langkah analisis sebagai berikut:

Pertama: Menentukan hipotesis

Ho: Tidak ada pengaruh antara variabel promosi penjualan terhadap keputusan kunjungan wisatawan.

H1: Ada pengaruh antara variabel promosi penjualan terhadap keputusan kunjungan wisatawan.

Kedua: Menghitung besarnya angka $t$ hitung

Hasil penghitungan SPSS diperoleh angka $t$ hitung sebesar 3,424.

Ketiga: Menghitung besarnya angka $t$ tabel dengan ketentuan sebagai berikut: Taraf signifikansi 0,05 dan Derajat Kebebasan (DK) dengan ketentuan $\mathrm{DK}=\mathrm{n}-2$, atau $120-2=118$. Berdasarkan ketentuan tersebut diperoleh angka $\mathrm{t}$ tabel sebesar 1.6579 .

Berdasarkan hasil penghitungan diperoleh angka $\mathrm{t}$ hitung sebesar 3,424 > $\mathrm{t}$ tabel sebesar 1.6579 maka Ho ditolak dan H1 diterima. Artinya ada pengaruh antara variabel promosi penjualan terhadap keputusan kunjungan wisatawan. Besarnya pengaruh variabel promosi penjualan terhadap keputusan kunjungan wisatawan sebesar 0,240 atau 24,0\%.

Untuk melihat apakah ada pengaruh antara variabel pemasaran langsung terhadap keputusan kunjungan wisatawan dilakukan langkah analisis sebagai berikut:

Pertama: Menentukan hipotesis

Ho: Tidak ada pengaruh antara variabel pemasaran langsung terhadap keputusan kunjungan wisatawan.

H1: Ada pengaruh antara variabel pemasaran langsung terhadap keputusan kunjungan wisatawan.

Kedua: Menghitung besarnya angka $t$ hitung
Hasil penghitungan SPSS diperoleh angka $t$ hitung sebesar 4,955.

Ketiga: Menghitung besarnya angka $t$ tabel dengan ketentuan sebagai berikut: Taraf signifikansi 0,05 dan Derajat Kebebasan (DK) dengan ketentuan $\quad \mathrm{DK}=\mathrm{n}$ -2 , atau $120-2=118$. Berdasarkan ketentuan tersebut diperoleh angka $t$ tabel sebesar 1.6579 .

Berdasarkan hasil penghitungan diperoleh angka $t$ hitung sebesar 4,955 $>t_{\text {tabel }}$ sebesar 1.6579 maka Ho ditolak dan H1 diterima. Artinya ada pengaruh antara variabel pemasaran langsung terhadap keputusan kunjungan wisatawan. Besarnya pengaruh variabel pemasaran langsung terhadap keputusan kunjungan wisatawan sebesar 0,334 atau 33,4 \%

Berdasarkan hasil analisis untuk mengetahui pengaruh variabel periklanan, promosi penjualan, dan pemasaran langsung terhadap keputusan kunjungan wisatawan, maka diperoleh persamaan regresi berganda sebagai berikut :

$Y=-2,168+0,409 X_{1}-0,186 X_{2}+0,246 X_{3}$ $+0,075 X_{4}+0,070 X_{5}+0,326 X_{6}$

\section{Interpretasi Koefisien Regresi}

Agar lebih mempertajam dan memperjelas terhadap apa yang telah dihasilkan dalam pengujian hipotesis yang ada, maka perlu dilakukan pembahasan terhadap hasil analisisnya. Model regresi berganda yang digunakan untuk memprediksi adalah :

$$
Y=-3,190+0,391 X_{1}+0,240 X_{2}+0,334 X_{3}
$$

Interpretasi terhadap koefisien regresi variabel bebas sangat penting, karena untuk mengetahui seberapa besar pengaruh periklanan, promosi penjualan, dan pemasaran langsung terhadap keputusan kunjungan wisatawan.

1. Koefisien regresi periklanan $\left(X_{1}\right)$ sebesar 0,190 mempunyai arti jika terjadi perubahan terhadap periklanan sebesar 1 satuan dengan asumsi variabel yang lain 
konstan, maka keputusan kunjungan wisatawan akan mengalami kenaikan sebesar 0,190. Berdasarkan uji t yang dilakukan diperoleh nilai sign.t $X_{1}$ sebesar 0,000 sehingga dapat dikatakan bahwa periklanan berpengaruh terhadap keputusan kunjungan wisatawan (Y).

2. Koefisien regresi promosi penjualan $\left(\mathrm{X}_{2}\right)$ sebesar 0,240 memberikan arti jika terjadi perubahan promosi penjualan sebesar 1 satuan dengan asumsi variabel yang lain konstan, maka keputusan kunjungan wisatawan akan mengalami kenaikan sebesar 0,240. Berdasarkan uji $\mathrm{t}$ yang dilakukan diperoleh nilai sign. $\mathrm{t}_{2}$ sebesar 0,001 sehingga dapat dikatakan bahwa promosi penjualanberpengaruh terhadap keputusan kunjungan wisatawan (Y).

3. Koefisien regresi pemasaran langsung $\left(\mathrm{X}_{3}\right)$ 0,334 memberikan arti jika terjadi perubahan terhadap pemasaran langsung sebesar 1 satuan dengan asumsi variabel yang lain konstan, maka keputusan kunjungan wisatawan akan mengalami peningkatan sebesar 0,334. Berdasarkan uji t yang dilakukan diperoleh nilai sign. $\mathrm{t} \mathrm{X}_{3}$ sebesar 0,000 sehingga dapat dikatakan bahwa pemasaran langsung berpengaruh terhadap keputusan kunjungan wisatawan (Y).

\section{KESIMPULAN DAN SARAN}

Berdasarkan hasil perhitungan dan analisis penelitian yang bertujuan untuk mengetahui pengaruh periklanan, promosi penjualan, dan pemasaran langsung terhadap keputusan kunjungan wisatawan (studi pada objek wisata air Water Fun Kota Palembang), maka diperoleh hasil sebagai berikut : Berdasarkan hasil perhitungan diperoleh angka $\mathrm{F}_{\text {hitung }}$ sebesar $77.228>\mathrm{F}_{\text {tabel }}$ sebesar 3,2288 dengan signifikansi sebesar $0,000<$ 0,05, sehingga Ho ditolak dan H1 diterima. Artinya ada pengaruh antara variabel periklanan, promosi penjualan, dan pemasaran langsung secara simultan terhadap keputusan kunjungan wisatawan. Berdasarkan hasil penghitungan diperoleh angka $\mathrm{t}$ hitung sebesar 5,388 $>\mathrm{t}$ tabel sebesar 1.6579 maka Ho ditolak dan H1 diterima. Artinya ada pengaruh antara variabel periklanan terhadap keputusan kunjungan wisatawan. Besarnya pengaruh variabel periklanan terhadap keputusan kunjungan wisatawan sebesar 0,391 atau 39,1\%. Berdasarkan hasil penghitungan diperoleh angka $\mathrm{t}$ hitung sebesar 3,424 > t tabel sebesar 1.6579 maka Ho ditolak dan H1 diterima. Artinya ada pengaruh antara variabel promosi penjualan terhadap keputusan kunjungan wisatawan. Besarnya pengaruh variabel promosi penjualan terhadap keputusan kunjungan wisatawan sebesar 0,240 atau 24,0 \%. Berdasarkan hasil penghitungan diperoleh angka $t$ hitung sebesar 4,955 > t tabel sebesar 1.6579 maka Ho ditolak dan $\mathrm{H} 1$ diterima. Artinya ada pengaruh antara variabel pemasaran langsung terhadap keputusan kunjungan wisatawan. Besarnya pengaruh variabel pemasaran langsung terhadap keputusan kunjungan wisatawan sebesar 0,334 atau 33,4\%.

Berdasarkan hasil analisis data dan wawancara yang telah dilakukan dengan responden maka akan diajukan beberapa saran sebagai berikut : Pihak Pengelola Objek Wisata Air Water Fun Kota Palembang harus mempertahankan dan apabila memungkinkan untuk meningkatkan promosi melalui periklanan, promosi penjualan, dan pemasaran langsung sehingga wisatawan akan tetap memutuskan untuk berkunjung ke Objek Wisata Air Water Fun. Pihak Pengelola Objek Wisata Air Water Fun Kota Palembang harus memperbaiki dan meningkatkan kualitas pelayanan kepada pengunjung sehingga kepuasan pelanggan akan semakin meningkat.

\section{DAFTAR PUSTAKA}

Ferdinand, A. (2006). Metode Penelitian Manajemen: Pedoman Penelitian Untuk Penulisan Skripsi, Tesis dan Disertasi Ilmu Manajemen. Semarang: Badan Penerbit Universitas Diponegoro 
Ghozali, I. (2006). Aplikasi Analisis Multivariate Dengan Program SPSS. Semarang: Badan Penerbit Universitas Diponegoro

Kotler, P., \& Keller, K.L. (2004). Manajemen Pemasaran Edisi 13, Cetakan IV, Alih Bahasa oleh Benyamin Molan.

Kotler, P. \& Amstrong, G. (2001). PrinsipPrinsip Pemasaran. Edisi Delapan. Jilid I. Jakarta: Erlangga

Nirwandar, S. (2013). Pembangunan Sektor Pariwisata di Daerah Otonomi Daerah. Diambil dari: http://www.tanjabtimkab.go.id/v2/inde $\mathrm{x}$ pembangunan sector pariwisata di era otonomi daerah \& format (diakses 13 Agustus 2015).

Sugiyono. (2009). Metode Penelitian Bisnis (Pendekatan Kuantitatif, Kualitatif, dan $R \& D)$. Bandung: Alfabeta

Swastha, B. (2002). Manajemen Pemasaran. Edisi Kedua. Cetakan Kedelapan. Jakarta: Penerbit Liberty

Tjiptono, F. (2001). Strategi Pemasaran. Edisi Pertama. Yogyakarta. Andi Ofset

Tjipto, F. (2000). Perspektif Manajemen dan Pemasaran Kontemporer. Yogyakarta: Andi Offset 